\title{
Effect of Gibberellic Acid, Indole Acetic Acid and Ethylene Gas on The In vitro Biocontrol Activity of Trichoderma harzianum Refai Against Alternaria solani and Botrytis cinerea.
}

\author{
M. A. Foaad \\ Department of Biological and Geological Sciences. Faculty of \\ Education, Ain Shams University, Cairo, Egypt.
}

\begin{abstract}
1 LTERNARIA solani and Botrytis cinerea were isolated $A$ from molds infecting tomato plant in Egypt. The biocontrol activity of Trichoderma harzianum Refai against these two pathogens were investigated in presence and in absence of growth regulators The antagonistic activity of $T$. harzianum against these two pathogens were affected by the presence of growth regulators. IAA and $\mathrm{GA}_{3}$ alone or in combination was stimulator for Alternaria solani; however this stimulation was suppressed in dual culture with $T$. harzianum. Ethylene gas was stimulator for the growth of Botrytis cinerea, although this stimulation was hampered when the ethylene gas and $T$. harzianum were existing together. Although, IAA and $\mathrm{GA}_{3}$ alone or in combinations stimulated Alternaria solani especially at low concentrations, it couldn't affect the growth of T.harzianum .The hormones mycoparasitism relationship were monitored by endopolygalacturonase , $\beta$-1, 3- glucanase, and Endo-chitinases enzymes . The secretion of endo- PG from A. solani was reduced when it was grown in the presence of IAA and $\mathrm{GA}_{3}$ when they were used separate or in mixture .The secretion of endo-PG from $T$. harzianum was increased as the hormones were also increased, but in the presence of the phytopathogens the secretion was reduced.The activity of enzymes were increased at concentrations less than $40 \mathrm{ppm}$ for both IAA and $\mathrm{GA}_{3}$ and at concentrations less than $75 \mathrm{ppm}$ for ethylene. The hormones separatley or in mixture couldn't affect the secretion of Endo-chitinase (endo- $\mathrm{CH}$ ) and $\beta-1,3$ - glucanase from T. harzianum directly but it act together with the phytopathogen. Ethylene gas was stimulator for Botrytis cinerea but it couldn't affect the growth of T.harzianum .
\end{abstract}

Keywords: Growth hormones, Alternaria solani, Trichoderma harzianum, Botrytis cinerea, Enzymes.

Phytopathogens are responsible for considerable losses $(\$ 30-\$ 50$ billion annually) in crops (Baker et al., 1997). No other single fungal genus has received as much attention as the Trichoderma spp for biocontrol of plant pathogens. Trichoderma harzianum p1 was used in vitro and in vivo to suppress many phytopathogens (Latorre et al., 1997). Some commercial products of Trichoderma spp. were used such as (Belgium ) against Rhizoctonia solani, 
Pythium spp. and Fusarium verticillium; Tricodex and Trichopulvin $25 \mathrm{PU}$ against Botrytis of vegetables and grapevines (Monte, 2001). The development of combinatory approaches that involve two or more biocontrol components, each occupying a different environmental niche and / or expressing a different mode of action, will improve the consistency and efficacy of the biocontrol activity (Schmitt et al., 2002). The presence of growth regulators such as auxins, gibberellins and ethylene in the soil come from applications done to the plants or even produced by some fungal pathogens could affect the phytopathogencity biocontrol relationship or to mediate fungal-plant interaction (Cristescu et al., 2002). High concentrations of IAA can inhibit the hypersensitive response (Robinette \& Matthysse, 1990 and Jouanneau et al., 1991) and may suppress expression of plant defense genes or give similar disease symptoms (Tudzynski \& Sharon, 2002).

Chitinolytic enzymes and $\beta-1,3-$-Glucanases which produced extracellular by Trichoderma spp. are well-known pathogenesis-related proteins (Whipps, 1992 and Zimand et al., 1996). Furthermore, they can also work indirectly by releasing oligosaccharides that can act as elicitors to activate other plant defense responses (Shibuya \& Minami, 2001). It has been claimed that these two enzymes are a battery of antibiotic substances produced by Trichoderma spp. (Ghisalberti \& Sivassithamparam, 1991). The presence of growth regulators in the soil could affect the activity of these enzymes (Aub et al., 1993).

Alternaria solani and Botrytis cinerea are plant necrotrophic pathogen that colonizes senescent or dead plant tissues and causes softening of fruits. Alternaria solani is the causal agent of early blight (EB) disease, infects aerial parts of tomato at both seedling and adult plant stages (Chaerani et al., 2007). On the other hand, $B$. cinerea attacks different plant tissues and has a broad host range. Furthermore , $B$. cinerea can synthesize ethylene themselves to assess in attacking the plant tissues and rapid maturity of the infected fruits (Cristescu et al., 2002). The role of ethylene in plant-pathogen interactions is complex (Díaz et al., 2002). The availability of the new tools for studying $B$. cinerea biology will make the characterization of fungusproduced ethylene in pathogenesis possible, and it will provide more answers on the physiology of the event of $B$. cinerea infection in fruits with respect to biocontrol . Recently, it has been reported that ethylene is a primary marker for fruit pathogenesis and several other infection-related plant products have also been studied as early markers of pathogenesis (Polevaya et al., 2002). Knowledge of the factors that could affect biocontrol activity would allow improving the biocontrol conditions. Limited information is available concerning the role of the plant growth regulators on the relationship between Trichoderma spp. and phytopathogens (Aub et al., 1993 and Badri et al., 2007). It is necessary to provide the information of how growth regulators secreted by the pathogens or pollute the soil could benefit or decrease the biocontrol effect of biocontrol organism. So,the aim of the present work was to investigate the role of IAA, GA3 and ethylene gas on the in vitro biocontrol activity of Trichoderma harzianum Refai strain against the most two tomato pathogens , Alternaria solani and Botrytis cinerea .

Egypt. J. Microbiol. 43 (2008) 


\section{Materials and Methods}

\section{Chemicals}

All chemicals and plant hormones were purchased from Sigma Aldrich Company. Ethylene gas and medical air were purchased from the Egyptian Company for Artificial Gases, Cairo, Egypt.

\section{Microorganisms}

Alternaria solani was isolated from mold infecting tomato fruits and were maintained on potato dextrose agar according to the method described by Kennedy et al. (2000) and Strobel \& Daisy (2003). Briefly, infected tissues are thoroughly surface treated with $70 \%$ ethanol. With a sterile knife blade, outer tissues are removed from the samples and the inner tissues are carefully excised and placed on water agar plates. After seven days of incubation, at $25^{\circ} \mathrm{C}$, hyphal tips of the fungi are removed and transferred to potato dextrose agar. Botrytis cinerea was isolated from the infected tissues according to the method of Kritzman \& Netzer (1978). The infected tissues rinsed in deionized water for $60 \mathrm{~min}$, then dried in a laminar flow hood on paper towels sterilized with $70 \%$ ethyl alcohol, and plated onto Kritzman's agar. The seed plates were incubated at $24^{\circ} \mathrm{C}$ with $12 \mathrm{~h}$ of day and $12 \mathrm{~h}$ of night (cool white fluorescent light by day) for 14 days, and examined microscopically (up to $\times 100$ magnification) for development of the fungus. The cultures were then transferred to acidified potato dextrose agar for the following studies. Identification of isolates based on colony morphology, rate of colony growth, sporulation, and sclerotium characteristics (Gilman, 1957; Ellis, 1971 and Barnett \& Hunter, 1998). Trichoderma harzianum Refai EMCC 583 was obtained from Egypt Microbial Culture Collection (Cairo Mircen), Faculty of Agriculture, Ain Shams University.

Preparation of inocula of A.solani and B. cinerea.

Isolates of A.solani and B. cinerea were maintained on potato dextrose agar (PDA) plates for 14 days at $25^{\circ} \mathrm{C}$ before inocula were isolated. To prepare a spore suspension, the fungus was removed from the cultured plates by gentle brushing of the plate surfaces with a sterile platinum loop and was suspended in distilled water. The fungal suspension was filtered through two layers of gauze under sterile conditions to separate the spores. The concentration of spores was determined by using a haemocytometer. Inocula of each fungus have $10^{5}$ spores $\mathrm{ml}^{-1}$ was prepared in sterilized water supplemented with $0.03 \%$ Tween 20 to ensure uniform distribution of the spores.

Biocontrol activity of Trichoderma harzianum against Alternaria solani in presence of growth hormones

Disks $(0.5 \mathrm{~cm}$ diameter) from pure cultures of $A$. solani were seeded with T. harzianum in a $9 \mathrm{~cm}$ Petri dishes containing autoclaved PDA separately or in dual cultures. Gibberellic acid $\left(\mathrm{GA}_{3}\right)$ or indole acetic acid (IAA) was added at 0 , $10,20,40,60$, and $80,160 \mathrm{ppm}$ before the inoculation of the fungi and after cooling the medium. Fungi were grown up to ten days at $28^{\circ} \mathrm{C} \pm 2^{\circ} \mathrm{C}$. Colony 
diameter was observed every two days and finally recorded at the tenth day. Dual cultures of $A$. solani and $T$. harzianum were seeded in the same dish at opposite sides and their growth was evaluated with radial growth of both. For each treatment, triplicate sets were run with six Petri dishes of the same procedure and repeated for three independent experiments. Control experiments were performed with seeding each fungus against itself.

In vitro growth of $B$. cinerea and ethylene production

The isolate of $B$. cinerea obtained from infected tomato fruits was investigated to produce ethylene in vitro by the method of Simona et al. (2002) with slight modification. Briefly, the isolate was grown on PDA supplemented with $35 \mathrm{mM}$ of L-methionine (an ethylene precursor). The precursor was added to PDA, and the $\mathrm{pH}$ of the medium was then adjusted to 3.8 before autoclaving. Portions $(160 \mu \mathrm{l})$ of a suspension containing a $10^{5}$ of conidia were uniformly plated by placing on 9-cm-diameter Petri dishes containing solidified PDA. For each treatment, Petri dishes with the same previous procedure were placed into Desiccator jars in five groups, each one has triplicate samples. The Desiccator jars are incubated for $120 \mathrm{~h}$ at $28^{\circ} \mathrm{C} \pm 2^{\circ} \mathrm{C}$. The ethylene emission was detected at $24 \mathrm{~h}$ intervals up to $120 \mathrm{~h}$. To accurate detection of ethylene gas emission, the experimental groups were removed from the incubator one by one at the end of each incubation time and the gas collected was estimated per volume of Desiccator jar as ppm.

\section{Analysis of gas concentrations}

Ethylene / air mixtures were prepared by mixing medical air with ethylene, to achieve the appropriate final ethylene concentration for use in the flow through system. Ethylene concentrations were monitored by Gas Chromatography (GC) using (Carle AGC series 400, HACH Carle Chromatography. Detector tube was model / type 8014-2805, its limits from 20-2000 ppm. Standard was analyzed prior to analysis of each set of samples. Sample concentrations were calculated based on the concentration of standards. In all gas experiments the design system was adjusted at flow rate $50 \mathrm{nl} \mathrm{h}^{-1}$ to remain the concentration of gas constant under the selected concentrations.

Effect of ethylene on the biocontrol activity of Trichoderma harzianum against Botrytis cinerea

Disks (0.5 cm diameter) from Botrytis cinerea was seeded with T. harzianum in a Petri dish containing autoclaved PDA separately or in dual cultures then ethylene gas was supplied at concentrations $0,25,50,75,100,150$ and $200 \mathrm{ppm}$. Fungi were grown up to ten days at $28^{\circ} \mathrm{C} \pm 2{ }^{\circ} \mathrm{C}$. Colony diameter was observed every two days and finally recorded at the tenth day. In case of dual cultures, controls were performed seeding each fungus against itself. Ethylene treatment was conducted in Desiccator jars using a novel flow through system described by Roze et al. (2004). Where no ethylene was added ethylene scrubbers (5.5 g $\mathrm{KMNO}_{4}$ ) were placed in the Desiccator jars to minimize effects due to production of the gas by the fungus. Air/gas mixtures were water saturated by passing medical air and ethylene through a sparger containing sterilized distilled Egypt. J. Microbiol. 43 (2008) 
water. For each treatment, triplicates sets were run with six Petri dishes of the same procedure and repeated for three independent experiments. Finally at the end of incubation the data were analyzed statistically.

Spore germination in presence of growth regulators

In vitro spore germination was tested in 96-well micro titer plates essentially as previously described with some modifications (Lorito et al., 1994). Briefly, a suspension of $3 \times 10^{3}$ spores of the experimental fungi and $50 \mu$ of broth culture (PDB) with $5 \mathrm{mM}$ potassium phosphate buffer $(\mathrm{pH}$ 6.7) were placed in a well of a micro titer plate, and $10 \mu \mathrm{l}$ of the tested hormone concentration (IAA,GA3 or mixture of (IAA + GA3 , 1:1) was supplemented under the same previous conditions. Addition of $10 \mu 1 \mathrm{H}_{2} \mathrm{O}$ instead of the hormone supply was used as a control. The ethylene gas was supplied under the same concentrations and conditions that were described previously. The germination tube length and the number of germinated spores were measured after $8 \mathrm{~h}$ of incubation.

Effect of growth regulators (IAA, GA3 and ethylene) on the enzymes activity for T. harzianum, Alternaria solani and Botrytis cinerea

Endo-polygalacturonase (endo-PG) activity

The secretion of Endo-polygalacturonase was evaluated in submerged broth culture (PDB) supplemented with hormones as described previously. For each treatement , $250 \mathrm{ml}$ Erlenmeyer flasks, containing $50 \mathrm{ml}$ of PDB supplemented with $10 \mathrm{~g} \mathrm{l}^{-1}$ citrus pectin were inoculated with $10^{5}$ spores of either two pathogens or T. harzianum in absence or the presence of different concentrations of growth hormones. To investigate the effect of $T$. harzianum on the ability of A. solani or Botrytis cinerea to secrete endo-PG, $10^{5}$ conidia of each fungus were inoculated under the same conditions to give a final concentration of $2 \times 10^{5}$ conidia per flask then incubated at $28{ }^{\circ} \mathrm{C} \pm 2{ }^{\circ} \mathrm{C}$ for 7 days. After the end of incubation ,the whole medium was then centrifuged at 9,000 x $g$ for $10 \mathrm{~min}$ to remove mycelia, and the supernatant was used to test endo-PG. Endopolygalacturonase (endo-PG) activity for the two pathogens was tested by a modified Nelson-Somogyi assay (Nelson, 1944). The reaction mixture contained $0.5 \%(\mathrm{w} / \mathrm{v})$ polygalacturonic acid in $100-\mathrm{mM}$ sodium acetate pH 5.2 (Pérez et al., 1991). One unit was defined as the amount of enzyme that released $1 \mathrm{mM}$ of reducing sugars per minute. Controls of the enzyme activity were performed with boiled enzyme $(20 \mathrm{~min})$. The results correspond to the mean of six different experiments run in triplicates. To test the effect of growth hormones on the biosynthesis of endo-PG by $T$. harzianum, it grows alone under the same conditions of the dual culture then the enzyme was assayed.

Endo-chitinase (endo-CH) activity of Trichoderma harzianum

The secretion of Endo- chitinase enzyme was evaluated in submerged (PDB) broth supplemented with hormones as described previously. For each treatment, $250 \mathrm{ml}$ Erlenmeyer flasks, containing $50 \mathrm{ml}$ of PDB broth supplemented with $1 \%$ glycol chitin were inoculated with $10^{5}$ spores of either two pathogens or $T$. harzianum in absence or the presence of different concentrations of growth 
hormones. Endochitinase activity of $T$. harzianum strain was tested by the method of Rojas-Avelipaz et al. (1999). To test the effect of A. solani or Botrytis cinerea on the ability of $T$. harzianum to secrete endo- $\mathrm{CH}, 10^{5}$ conidia of each fungus were inoculated in the same media to give a final concentration of $2 \times 10^{5}$ conidia per flask. Flasks were incubated at $28^{\circ} \mathrm{C} \pm 2^{\circ} \mathrm{C}$ up to 10 days with shaking at $150 \mathrm{rpm}$. The whole medium was then centrifuged at 9,000 x $g$ for $10 \mathrm{~min}$ to remove mycelia, and the supernatant was used to test endo- $\mathrm{CH}$ activity. One unit of the enzyme activity was defined as the amount of enzyme that releases $1 \mu \mathrm{mol}$ of $\mathrm{N}$-acetyl glucosamine per hour. The results correspond to the mean of six different experiments run in triplicates.

\section{$\beta$-1, 3-Glucanase activity}

In the previous described experiment, $\beta$-1, 3-Glucanase of $T$. harzianum was also assayed based on the release of reducing sugar from laminarin as described by Santos et al. (1977). One unit of enzyme activity (U) was defined as the amount of enzyme that catalyzes the equivalent release of one $\mu \mathrm{mol}$ of glucose per minute under the described assay conditions.

\section{Statistical analysis}

Data were analyzed through least significant differences using the statistical analysis system SPSS soft ware version 14 ( Robert \& Jane Gradwohl, 2005). Standard error bars of means for each treatment were expressed in the graphs.

\section{Results and Discussion}

Biocontrol activity of Trichoderma harzianum in presence of plant growth hormones

To study the mycoparasitism relationship between the biocontrol organism and the two pathogens in presence of hormones, the plan of investigations was designed to study such two parameters in separate and in dual cultures for both pathogens and T. harzianum. The results in Table 1 show that T.harzianum Refai has antagonistic activity against A.solani. When the hormones were added alone or in combination they have no effect on the growth of $T$. harzianum in absence of A.solani. On the other hand, the growth of A. solani was suppressed in the presence of concentration less than $40 \mathrm{ppm}$ while, an inhibitory activity increased when the concentrations of hormones increased than $40 \mathrm{ppm}$ alone or in dual cultures. The results are also indicated that the effect of IAA alone or in combination with $\mathrm{GA}_{3}$ was more inhibitory effect than $\mathrm{GA}_{3}$ alone. The growth of T. harzianum in dual cultures treated with the growth regulators increased significantly than in case of its use alone. These results proved that the hormones have no effect on the growth of $T$. harzianum. Therefore, the stimulation of T. harzianum is due to the presence of the phytopathogen not due to the treatment of hormones. Finally, the presence of T. harzianum and A. solani in combination with IAA, GA3 alone or in the mixture could increase the mycoparastism in vitro by $T$. harzianum. In this manner, IAA inhibited the growth of Agrobacterium and many other plant-associated bacteria but not the growth of bacteria that occupy other ecological niches (Pu Liu \& Nester, 2006). In the same respect, the growth of red pepper plants was enhanced by treatment Egypt. J. Microbiol. 43 (2008) 
with Rhizobacterium producing giberillic acid. (Joo et al., 2005). Although, no one could explain the effect of auxins and gibberellins on the fungi, Lu et al. (2000) discussed the effect of IAA on the basis of stimulation of the pathogen. The results of the present work are nearly in line with the results of Sharaf \& Farrag (2004) who found that 40 ppm of IAA inhibited the growth of Fusarium solani.

TABLE 1. Effect of different concentrations of IAA and $\mathrm{GA}_{3}$ on the growth of $T$. harzianum and $A$. solani in separate and in dual cultures.

\begin{tabular}{|c|c|c|c|c|c|}
\hline \multirow{2}{*}{$\begin{array}{c}\text { Growth } \\
\text { hormone }\end{array}$} & \multirow[b]{2}{*}{$\begin{array}{c}\text { Concentration } \\
\text { (ppm) }\end{array}$} & \multicolumn{4}{|c|}{ Colony diameter $(\mathrm{mm})$ of } \\
\hline & & $\begin{array}{c}T . \\
\text { harzianum } \\
\text { in separate } \\
\text { cultures } \\
\end{array}$ & $\begin{array}{l}\text { T. harzianum } \\
\text { in dual } \\
\text { cultures }\end{array}$ & $\begin{array}{c}\text { A. solani } \\
\text { in separate } \\
\text { cultures }\end{array}$ & $\begin{array}{l}\text { A. solani } \\
\text { in dual } \\
\text { cultures }\end{array}$ \\
\hline \multirow{6}{*}{ IAA } & 0.0 (control) & $81.2 \pm 0.31$ & $81.2 \pm 0.31$ & $52.1 \pm 0.24$ & $52.1 \pm 0.24$ \\
\hline & 20 & $81.4+0.24$ & $83.2+0.27$ & $53.3 * * \pm 0.22$ & $50.4 * * \pm 0.22$ \\
\hline & 40 & $82.1 \pm 0.33$ & $83.2 \pm 0.29$ & $56.8 * * \pm 0.19$ & $39.2 * * \pm 0.18$ \\
\hline & 60 & $81.9 \pm 0.28$ & $90.1 * *+0.24$ & $42.7 * * 0.12$ & $38.3 * *+0.29$ \\
\hline & 80 & $82.1 \pm 0.17$ & $92.3^{* *} \pm 0.20$ & $40.3 * * \pm 0.18$ & $34.5^{* *} \pm 0.23$ \\
\hline & 160 & $81.7 \pm 0.18$ & $88.6 * * \pm 0.12$ & $39.1 * * \pm 0.14$ & $20.2 * * \pm 0.22$ \\
\hline \multirow{6}{*}{$\mathrm{GA}_{3}$} & 0.0 (control) & $81.2 \pm 0.31$ & $81.2 \pm 0.31$ & $52.1 \pm 0.24$ & $52.1 \pm 0.24$ \\
\hline & 20 & $81.2 \pm 0.20$ & $85.5^{* *} \pm 0.29$ & $52.7 * * \pm 0.21$ & $51.6^{* * *} \pm 0.20$ \\
\hline & 40 & $81.4 \pm 0.26$ & $87.3 \pm 0.25$ & $53.8 * * 0.19$ & $50.8 * *+0.17$ \\
\hline & 60 & $81.9 \pm 0.16$ & $89.2 \pm 0.34$ & $47.9 * * \pm 0.22$ & $49.2 * * \pm 0.25$ \\
\hline & 80 & $81.1 \pm 0.28$ & $90.1 * * \pm 0.20$ & $46.4 * * \pm 0.17$ & $47.2 * * \pm 0.23$ \\
\hline & 160 & $81.7 \pm 0.21$ & $89.8 * * \pm 0.21$ & $40.6^{* *} \pm 0.10$ & $40.2 * * \pm 0.20$ \\
\hline \multirow{6}{*}{$\begin{array}{c}\text { Mixture } \\
\text { of } \\
\text { IAA and } \\
\mathrm{GA}_{3} \\
(1: 1)\end{array}$} & 0.0 (control) & $81.2 \pm 0.31$ & $81.2 \pm 0.30$ & $52.1 \pm 0.24$ & $52.1 \pm 0.24$ \\
\hline & 20 & $81.5+0.11$ & $85.3^{* *} \pm 0.25$ & $44.2 * * \pm 0.17$ & $40.4^{* *} \pm 0.20$ \\
\hline & 40 & $81.7 \pm 0.16$ & $87.4 * \pm 0.26$ & $38.9 * * \pm 0.15$ & $35.7 * * \pm 0.11$ \\
\hline & 60 & $81.6 \pm 0.19$ & $88.2 * * \pm 0.24$ & $31.1^{* * *} \pm 0.20$ & $26.7 * \pm 0.24$ \\
\hline & 80 & $81.9 \pm 0.12$ & $91.1 * * \pm 0.22$ & $24.6^{* *} \pm 0.15$ & $21.3^{* * *} \pm 0.19$ \\
\hline & 160 & $81.7 \pm 0.12$ & $87.2 * * \pm 0.20$ & $20.2 * * \pm 0.18$ & $18.8^{* *} \pm 0.20$ \\
\hline
\end{tabular}

** means highly significant L.S.D at $5 \%$.

Spore germination of Trichoderma harzianum and Alternaria solani in presence of growth regulators

The results in Table 2 show that the rate of spore germination of T. harzianum stay without change than control samples when they treated with IAA or $\mathrm{GA}_{3}$ separate or in combination. However, the germination tube length increased significantly at 40 and $60 \mathrm{ppm}$ if the hormones were used separate or in combination. The germination of A.solani spores was reduced; however the tube elongation was stimulated. These findings are in agreement with the results of Roco et al. (2001) who found that neither spore germination nor growth of $\mathrm{T}$. harzianum could be change in the presence of growth hormones except at $40 \mathrm{ppm}$ which was stimulator 
for T. harzianum growth in dual culture. In the same manner, Gryndler et al. (1998) stated that $30 \mu \mathrm{M}$ IAA completely suppressed the growth of Glomus mossae and G. fistilosum. Recently, Badri et al. (2007) found that the spore germination of both Fusarium oxysporum and T. harzianum were reduced in the presence of the growth hormones. They also found that $40 \mathrm{ppm}$ of $\mathrm{GA}_{3}$ didn't affect the germination of Fusarium oxysporum spores. All these findings showed a variation in hormonal response for both biocontrol organism and pathogen, the thing that indicated the effect of IAA and GA3 may be a strain dependent and complex.

TABLE 2. Percentage of in vitro spore germination and germ tube elongation of both T. harzianum and $A$. solani in presence of different concentrations of IAA- and GA3.

\begin{tabular}{|c|c|c|c|c|c|}
\hline $\begin{array}{c}\text { Growth } \\
\text { hormone }\end{array}$ & $\begin{array}{c}\text { Concentration } \\
(\mathbf{p p m})\end{array}$ & $\begin{array}{c}\text { Percentage of } \\
\text { Spore } \\
\text { germination of } \\
\text { T.harzianum }\end{array}$ & $\begin{array}{l}\text { Germ tube } \\
\text { length of } \\
T . \text { harizianum } \\
\quad(\mu \mathrm{m})\end{array}$ & $\begin{array}{l}\text { Percentage of } \\
\text { spore } \\
\text { germination of } \\
\text { A. solani }\end{array}$ & $\begin{array}{l}\text { Germ tube } \\
\text { length of } \\
\text { A.solani } \\
\text { ( } \mu \mathrm{m})\end{array}$ \\
\hline \multirow{6}{*}{ IAA } & 0.0 & $84.2 \pm 0.24$ & $124.2 \pm 1.0$ & $56.4 \pm 0.22$ & $88.3 \pm 0.9$ \\
\hline & 20 & $84.6 \pm 0.21$ & $124.7 \pm 2.3$ & $55.6^{* *} \pm 0.11$ & $92.4^{* *} \pm 1.4$ \\
\hline & 40 & $84.9 \pm 0.18$ & $133.2 * * \pm 1.0$ & $53.9 * * \pm 0.23$ & $97.9 * * \pm 1.3$ \\
\hline & 60 & $84.1 \pm 0.20$ & $127.2 * * \pm 2.0$ & $50.1 * * \pm 0.12$ & $98.3^{*} * \pm 0.8$ \\
\hline & 80 & $80.1 * * \pm 0.16$ & $107.3 * * \pm 1.5$ & $50.1 \pm 0.20$ & $90.3^{*} * 0.6$ \\
\hline & 160 & $80.9 \pm 0.22$ & $85.9 * * \pm 1.2$ & $56.9 * * \pm 0.22$ & $89.4^{* *} \pm 1.1$ \\
\hline \multirow{6}{*}{$\mathrm{GA}_{3}$} & 0.0 & $84.2 \pm 0.23$ & $124.2 \pm 1.0$ & $56.4 \pm 0.25$ & $88.3 \pm 0.9$ \\
\hline & 20 & $84.3 \pm 0.20$ & $128.9 * * \pm 1.3$ & $55.4 * * \pm 0.32$ & $90.3^{* *} \pm 1.4$ \\
\hline & 40 & $84.2 \pm 0.19$ & $125.4 * * \pm 1.0$ & $53.5 * * \pm 0.13$ & $92.6 * * \pm 0.7$ \\
\hline & 60 & $84.1 \pm 0.15$ & $124.5 \pm 1.2$ & $50.1 * * \pm 0.15$ & $95.4 * * \pm 1.2$ \\
\hline & 80 & $84.1 \pm 0.23$ & $85.4 * * \pm 1.6$ & $59.1 * * \pm 0.21$ & $90.4^{* *} \pm 0.6$ \\
\hline & 160 & $84.9 \pm 0.24$ & $64.3^{* *} \pm 1.1$ & $55.9 * * \pm 0.22$ & $91.1 * * \pm 1.2$ \\
\hline \multirow{6}{*}{$\begin{array}{c}\text { Mixture } \\
\text { of } \\
\text { IAA } \\
+ \\
\mathrm{GA}_{3} \\
(1: 1)\end{array}$} & 0.0 & $84.2 \pm 0.23$ & $124.2 \pm 1.0$ & $56.4 \pm 0.26$ & $88.3 \pm 0.9$ \\
\hline & 20 & $84.6 \pm 0.18$ & $137.6^{* *} \pm 1.5$ & $52.4 * * \pm 0.30$ & $94.1^{* *} \pm 1.4$ \\
\hline & 40 & $84.3 \pm 0.20$ & $131.8 * * \pm 1.3$ & $51.5 * * \pm 0.18$ & $99.7 * * \pm 2.0$ \\
\hline & 60 & $84.4+0.14$ & $126.4^{* *}+2.1$ & $50.1 * * \pm 0.14$ & $97.2 * * \pm 1.8$ \\
\hline & 80 & $84.4 \pm 0.11$ & $121.2 * *+1.0$ & $49.1 * * \pm 0.21$ & $95.4^{* *} \pm 1.5$ \\
\hline & 160 & $84.3 \pm 0.12$ & $121.2 \pm 1.0$ & $45.9^{* *} \pm 0.20$ & $93.9 * * \pm 1.2$ \\
\hline
\end{tabular}

** means highly significant L.S.D at $5 \%$. 
Effect of IAA and GA3 on the enzymes activity for both T. harzianum and Alternaria solani.

Endo-polygalacturonase (endo- $P G$ ) activity

Endo-polygalacturonase (endo-PG) are enzymes secreted by phytopathogens to dissolve the cell wall of the host and they also secreted by T. harzianum (Pérez et al., 1991 and Sicilia et al., 2005). The results (Fig. 1-3) showed that the secretion of endo- PG from A. solani was reduced when it was grown in the presence of these two growth regulators regardless they were used separate or in mixture. In this regard, the secretion of endo-PG from A. alternata (Pérez et al., 1991) into submerged cultures was reduced to $20-25 \%$ when this phytopathogen was grown in the presence of $40 \mathrm{ppm}$ of either IAA or $\mathrm{GA}_{3}$; these results suggested that the hormones interrupt the rate of the enzyme secretions because the rate of secretion decreased than control. A stronger inhibitory effect was observed in the presence of active T. harzianum, which may be explained as a consequence of the growth inhibitory effect of the biocontrol agent on A. solani. Due to the fact that $T$. harzianum also secretes endo-PG, and to avoid misleading in the results as a result of endopolygacturonase activity by $T$. harzianum, it was grown separately in presence and in absence of the growth hormones. The results in Fig. (1-3) show that the enzyme from $T$. harzianum was secreted increasingly as the hormone secretions were also increased than control, but in the presence of the phytopathogens the secretion was decreased. These results indicated that the effect of the hormones on the total endoploygalacturonase in a dual culture in vitro may introduce the expected inhibition of the A.solani in the presence of the biocontrol organism in a combination with hormones .In this respect, Pérez et al. (1991) stated that its level is much smaller than those secreted by A. alternata but it was necessary to determine if endo-PG secretion by $A$. solani was altered by the presence of the $T$. harzianum . These findings may be suggested that during antagonism T. harzianum affects cellular mechanisms in A. solani that result in a slow down in its development and in a decrease of its infectious ability based on the levels of secreted endo-PG.Similar results were obtained by Roco et al. (2001) . They mentioned that the addition of $10^{5} \mathrm{M}$ IAA or $\mathrm{GA}_{3}$ enhanced cellulase production by $T$. reese $i$ whereas higher concentrations were inhibitory.

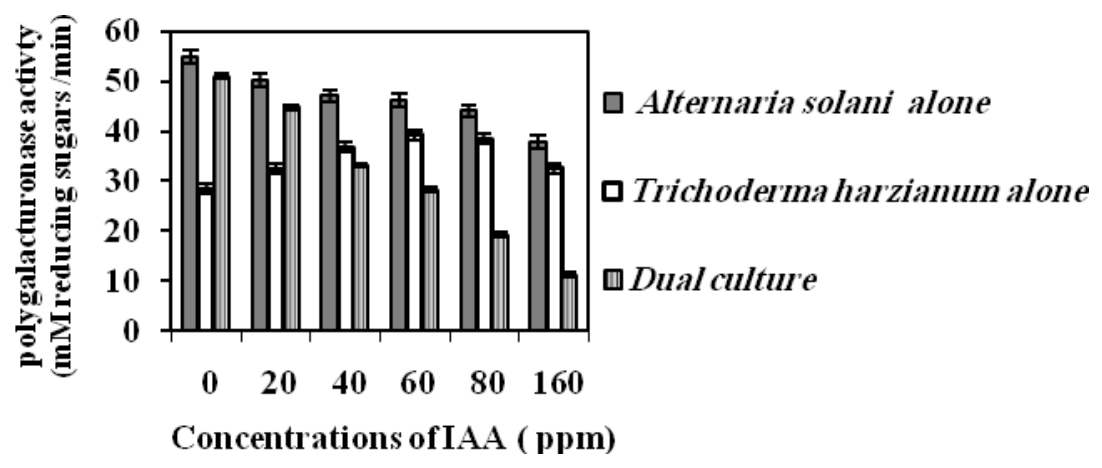

Fig. 1. Effect of IAA on Endo -polygalacturonase activity secreted by Alternaria solani and Trichoderma harzianum in both separate and in dual culture . 


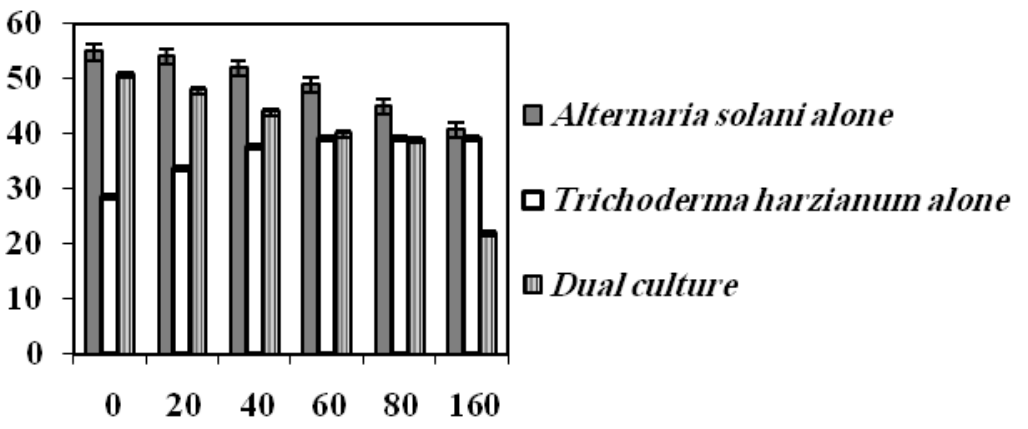

Concentrations of $\mathrm{GA}_{3}$ ( ppm)

Fig. 2. Effect of $\mathrm{GA}_{3}$ on polygalacturonase activity secreted by Alternaria solani and Trichoderma harzianum in both separate and in dual culture.

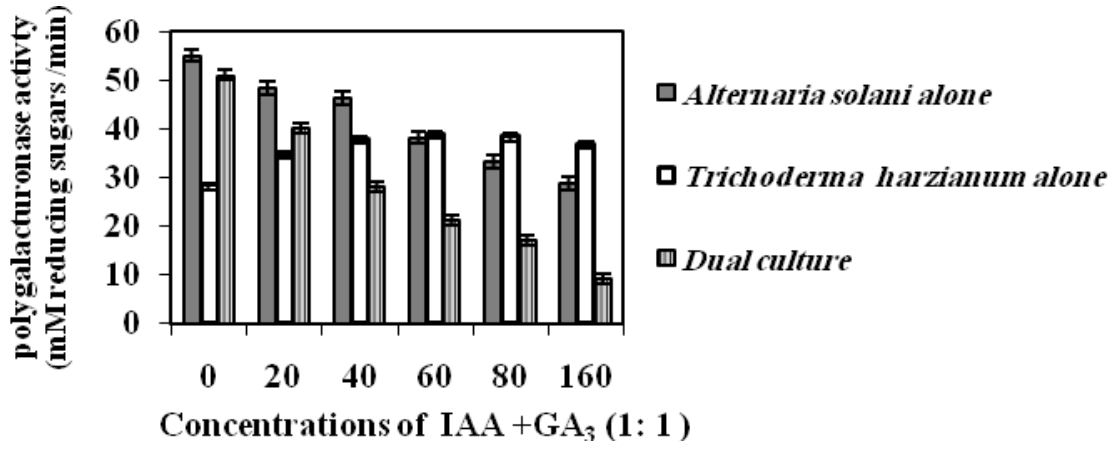

Fig. 3. Effect of mixture of IAA $+\mathrm{GA}_{3}$ on polygalacturonase activity secreted by Alternaria solani and Trichoderma harzianum in both separate and in dual culture.

Endo-chitinase (endo- $\mathrm{CH}$ ) and $\beta$-1, 3-Glucanase activity

The role of IAA and $\mathrm{GA}_{3}$ on Endo-chitinase (endo-CH) and $\beta-1,3-$ glucanase activity secreted from T.harzianum were represented in Fig. 4-9. The results show that the presence of 20,40,60, ppm of either IAA or $\mathrm{GA}_{3}$ could affect the ability of $T$. harzianum to secrete endo- $\mathrm{CH}$, however the secretion was reduced at 80 and $160 \mathrm{ppm}$. The results are also showed that the secretion is only increased in dual cultures while in separate cultures it still near to the control.This indicated that the two hormones separately or in mixture couldn't affect the secretion of enzymes directly but it act together with the phytopathogen. These results are in accordance of Haram et al. (1996). They suggested that the presence of the pathogen could serve as an additional inducer of this fungal cell wall degrading enzymes. Then, the presence of this pathogen would stimulate one of the mechanisms by T. harzianum for its biocontroller activity. The importance of Endo-chitinase (endo- $\mathrm{CH}$ ) and $\beta-1,3-$ glucanase activity in the inhibitory activity is due to the degradation of cell walls of

Egypt. J. Microbiol. 43 (2008) 
the pathogens. They can hydrolyze cell walls and inhibits spore germination and germ tube elongation of various fungi (De la Cruz et al., 1992 and Lorito et al., 1994). The results indicated that the stimulation of the two enzymes in T. harzianum is not due to the direct effect of the growth regulators on $T$. harzianum itself but due to the stimulation of $A$. solani that stimulate the mycoparasitism of $T$. harzianum by the enhancement of its antagonistic enzyme secretions.

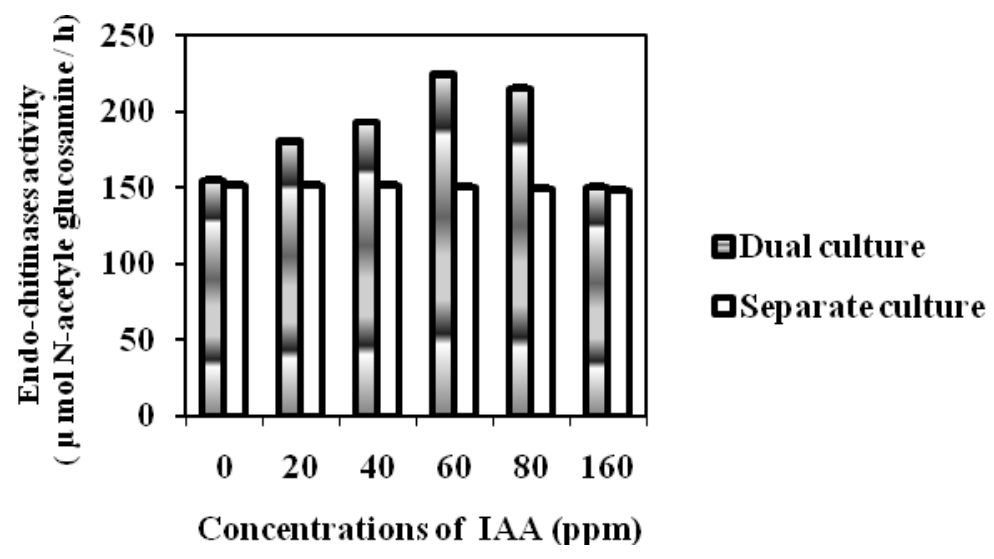

Fig. 4. Effect of different concentrations of IAA on Endo-chitinases activity of Trichoderma harzianum in separate and dual culture with Alternaria solani

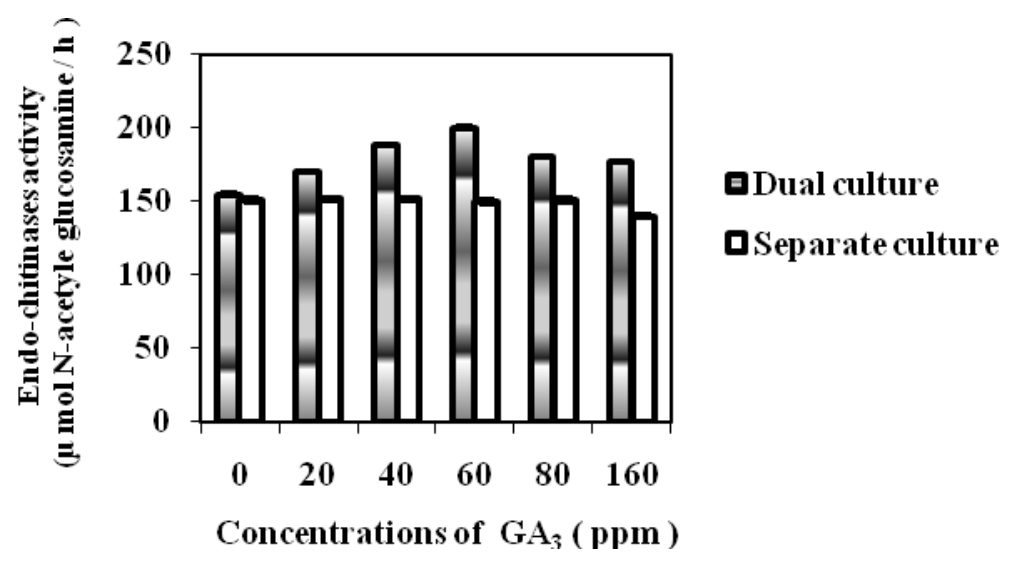

Fig. 5. Effect of different concentrations of $\mathrm{GA}_{3}$ on Endo-chitinase activity of Trichoderma harzianum in separate and in dual culture with Alternaria solani. 


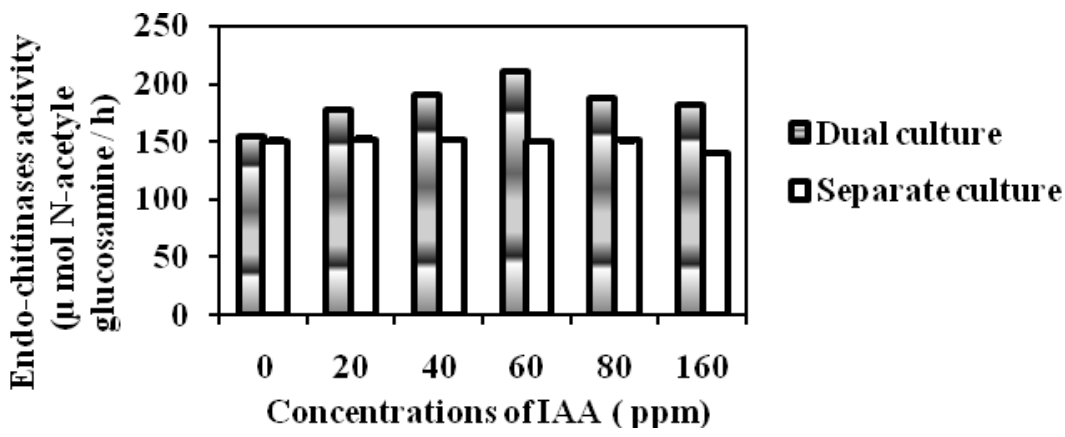

Fig. 6. Effect of IAA + $\mathrm{GA}_{3}$ on Endo-chitinase activity secreted by Trichoderma harzianum in both separate and in dual culture with Alternaria solani.

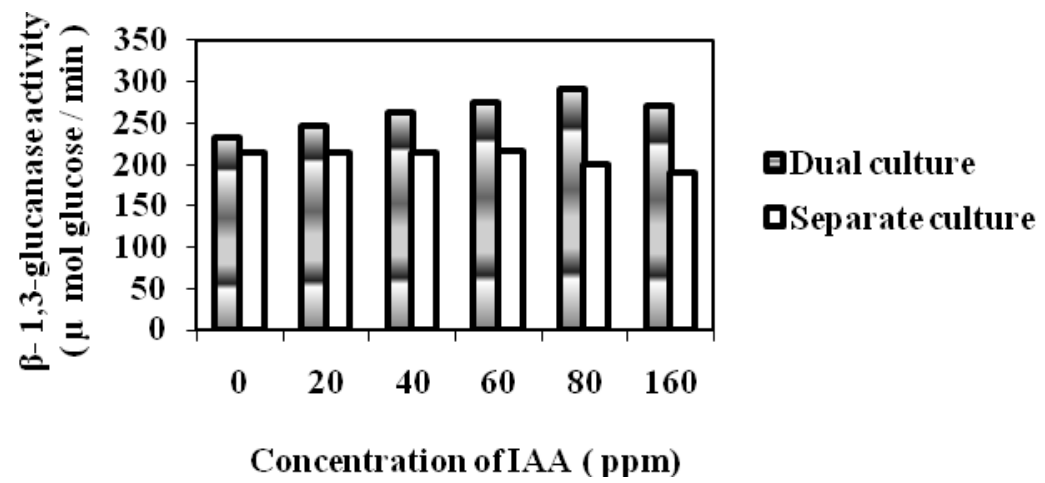

Fig. 7. Effect of IAA on $\beta-1,3$ - glucanase activity of Trichoderma harzianum in separate culture and in dual culture with Alternaria solani.

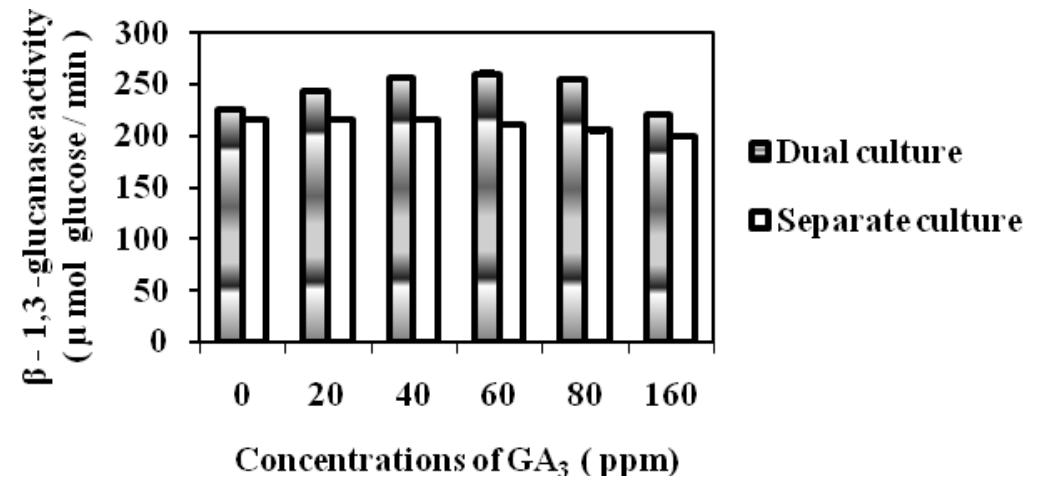

Fig. 8. Effect of GA3 on $\beta-1,3$ - glucanase activity of Trichoderma harzianum in separate culture and dual culture with Alternaria solani. 


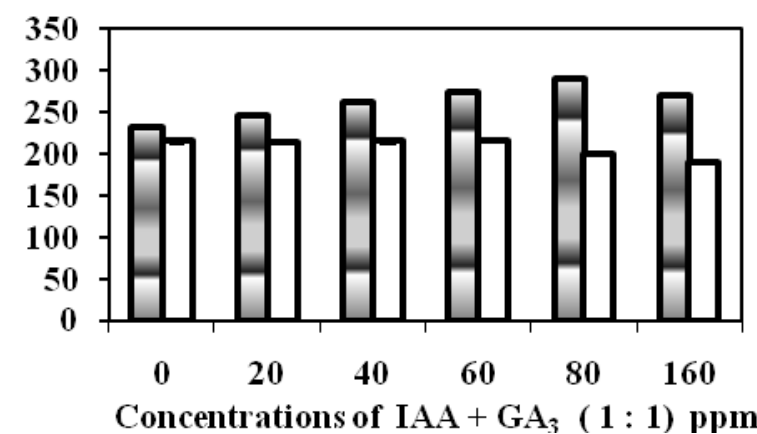

\section{EDual culture}

口Separate culture

Concentrations of IAA $+\mathrm{GA}_{3}(1: 1) \mathrm{ppm}$

Fig. 9. Effect of IAA + GA3 on $\beta$ - 1,3 - glucanase activity of Trichoderma harzianum in separate culture and in dual culture with Alternaria solani.

In vitro growth of $B$. cinerea and ethylene production

An increase of ethylene formation in pathogen-challenged plants has been related to defense responses leading to resistance as well as to symptoms development during pathogenesis. The role of ethylene in incompatible interactions is mostly contradictory and depends on the pathogen (Thomma et al., 1999). In addition, recent findings indicated the role of ethylene in systemic acquired resistance and in induced systemic resistance (Knoester et al., 1998). Literatures have been proved that some strains of Botrytis cinerea enable to produce ethylene gas to assess the pathogen in its attack the host. So, in the present study, the isolate of Botrytis cinerea isolated from infected tomatoes fruits was subjected to test its in vitro biosynthetic abilities to produce ethylene gas. The results (Fig. 10) show that the isolate of Botrytis cinerea enabled to produce ethylene in presence or absence of its precursor (methionine), although the production was more in presence of methionine. In this regard, Qadir et al. (1997) found that the maximum amount of ethylene was produced by grey mold isolated from tomatoes grown on PDA supplemented with $35 \mathrm{mM}$ L-methionine after 7 days. In the same line, Chagué et al. (2002) stated that Botrytis cinerea during the first $48 \mathrm{~h}$ of culture the fungus uses methionine to produce ethylene in vitro.

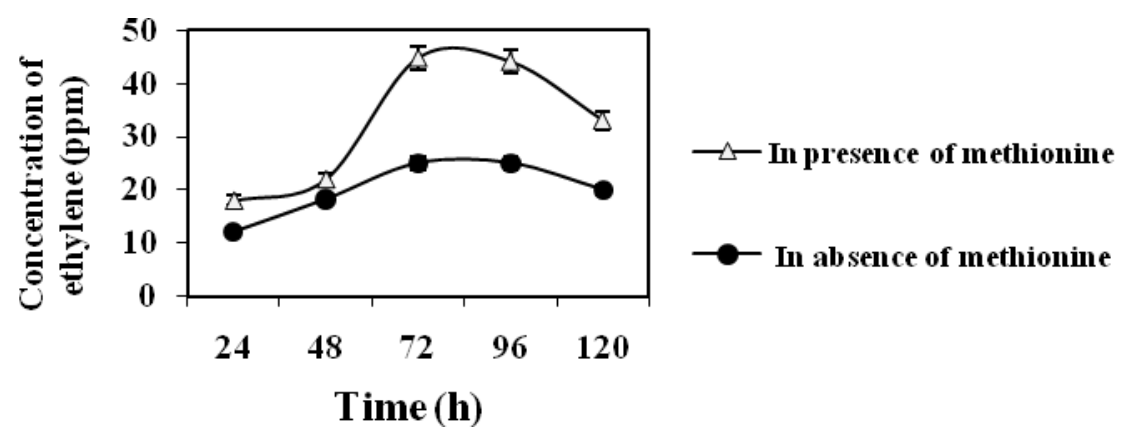

Fig. 10. Time course of ethylene production by Botrytis cinerea on PDA in the presence and absence of methionine for $120 \mathrm{hr}$ at $24 \mathrm{hr}$ intervals. 
TABLE 3. Effect of Different concentrations of ethylene on the growth of $T$. harzianum and Botrytis cinerea in separate and in dual cultures after incubation at $28^{\circ} \mathrm{C}$ for one week.

\begin{tabular}{|c|c|c|c|c|}
\hline \multirow{2}{*}{$\begin{array}{c}\text { Concentrations } \\
\text { of ethylene } \\
\text { (ppm) }\end{array}$} & $\begin{array}{c}\text { Trichoderma } \\
\text { harzianum } \\
\text { in separate } \\
\text { culture }\end{array}$ & $\begin{array}{c}\text { Trichoderma } \\
\text { harzianum } \\
\text { in dual culture }\end{array}$ & $\begin{array}{c}\text { Botrytis } \\
\text { cinerea } \\
\text { in separate } \\
\text { culture }\end{array}$ & $\begin{array}{c}\text { Botrytis } \\
\text { cinerea } \\
\text { in dual } \\
\text { culture }\end{array}$ \\
\hline $0.0($ control) & $83.2 \pm 0.31$ & $85.23 \pm 0.22$ & $69.5 \pm 0.33$ & $67.3 \pm 0.14$ \\
\hline 25 & $84.7 * * \pm 0.21$ & $94.11^{* *} \pm 0.15$ & $71.22^{* *} \pm 0.15$ & $69.25^{* *} \pm 0.22$ \\
\hline 50 & $87.4^{* *} \pm 0.22$ & $96.4^{* *} \pm 0.18$ & $74.33^{* *} \pm 0.40$ & $70.13^{* *} \pm 0.19$ \\
\hline 75 & $89.2^{* *} \pm 0.18$ & $99.2^{* *} \pm 0.11$ & $75.2^{* *} \pm 0.25$ & $69.18^{* *} \pm 0.14$ \\
\hline 100 & $83.1 * * \pm 0.27$ & $92.2^{* *} \pm 0.20$ & $70.11^{* *} \pm 0.16$ & $56.15^{* *} \pm 0.13$ \\
\hline 200 & $83.6 \pm 0.10$ & $87.2^{* *} \pm 0.12^{* *}$ & $68.22^{* *} \pm 0.10$ & $45.14^{* *} \pm 0.50$ \\
\hline
\end{tabular}

** means highly significant L.S.D at $5 \%$.

Effect of ethylene on the biocontrol activity of Trichoderma harzianum against Botrytis cinerea

Limited studies have been focused concerning the role of ethylene on microorganisms but the exposure to exogenous ethylene has been demonstrated to escalate the biosynthesis of endogenous ethylene and to enhance the rate of membrane lipid breakdown (Kim \& Wills, 1995) Mechanisms of B. cinerea suppression by different Trichoderma spp. are diverse (Rey et al., 2001 and Hanson \& Howell, 2004). The results (Table 3) show that ethylene was a stimulator for both T. harzianum and Botrytis cinerea at the first three concentrations when they grown alone. On the other hand, in case of dual cultures the growth of T. harzianum was increased significantly while growth of Botrytis cinerea decreased significantly than that of separate culture. This may be due to the mycoparasitism of $T$. harzianum against Botrytis cinerea occurred following the suppression of ethylene production. This hypothesis was confirmed in results shown in Fig 11. The results showed that the biosynthesis of ethylene in dual culture was decreased than separate cultures which is consequently suppress the growth of Botrytis cinerea .In this regard, Elad \& Eversen (1995) stated that grey mold development is associated with an increase in ethylene production from the infected tissues, which is most often attributed to the host plant. The level of ethylene production by $B$. cinerea-infected tomatoes was significantly higher than the level in mock-infected tomatoes and started to increase before there was visible decay (Polevaya et al., 2002). The results (Table 4) show similar results in spore germination and germ tube elongation for both pathogen and the biocontrol organism. In this manner, Díaz et al. (2002) found that exogenously applied ethylene was shown to stimulate gray mold, caused by $B$. cinerea, on tomato, pepper, cucumber, bean, rose, and carnation. All these data showed that ethylene is being stimulator for Botrytis cinerea when it exists alone in absence of the biocontrol organism. Moreover, the presence of

Egypt. J. Microbiol. 43 (2008) 
T. harzianum and Botrytis cinerea together suppress the production of ethylene and consequently, the growth of Botrytis cinerea. When ethylene was supplied exogenously it leads to the stimulation of mycoparasitism and inhibition of the pathogen.

TABLE 4. Percentage of in vitro spore germination and germ tube elongation of both T. harzianum and Botrytis cinerea in presence of different concentrations of ethylene gas.

\begin{tabular}{|c|c|c|c|c|}
\hline $\begin{array}{c}\text { Concentration } \\
\text { of ethylene } \\
\text { (ppm) }\end{array}$ & $\begin{array}{c}\begin{array}{c}\text { Percentage of } \\
\text { spore }\end{array} \\
\text { germination } \\
\text { of } \\
\text { Trichoderma } \\
\text { harzianum }\end{array}$ & $\begin{array}{l}\text { Germ tube } \\
\text { length of } \\
\text { Trichoderma } \\
\text { harzianum } \\
(\boldsymbol{\mu m})\end{array}$ & $\begin{array}{c}\text { Percentage of } \\
\text { spore } \\
\text { germination } \\
\text { of } \\
\text { Botrytis } \\
\text { cinerea }\end{array}$ & $\begin{array}{l}\text { Germ tube } \\
\text { length of } \\
\text { Botrytis } \\
\text { cinerea } \\
(\mu \mathrm{m})\end{array}$ \\
\hline 0.0 (Control) & $83.6+0.20$ & $124.8+1.3$ & $62.5+0.33$ & $92.5 \pm 1.2$ \\
\hline 25 & $83.8+0.17$ & $124.5 \pm 1.4$ & $65.4 * *+0.99$ & $99.1 * *+1.5$ \\
\hline 50 & $83.1 \pm 0.10$ & $124.9 * * \pm 1.8$ & $70.1 * * \pm 0.82$ & $102.4 * * \pm 2.1$ \\
\hline 75 & $83.1+0.25$ & $120.1 * * \pm 1.1$ & $84.2 * *+0.76$ & $106.6 * *+2.2$ \\
\hline 100 & $83.5^{* *}+0.22$ & $117.2 * *+1.0$ & $76.1+0.44$ & $94.5 * *+1.3$ \\
\hline 200 & $83.7 \pm 0.15$ & $111.3 * * \pm 1.7$ & $60.3^{* *}+0.41$ & $88.2^{* *} \pm 0.9$ \\
\hline
\end{tabular}

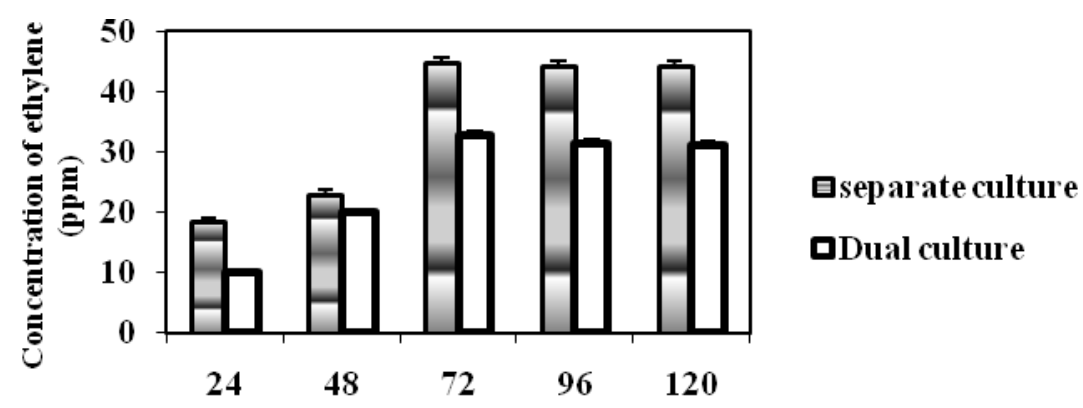

Time (h)

Fig. 11. Time course of ethylene production by Botrytis cinerea on PDA media in separate and in dual culture with Trichoderma harzianum for $120 \mathrm{~h}$ at $24 \mathrm{hr}$ intervals.

Effect of ethylene on the enzymes activity for both T. harzianum and Botrytis cinerea

The results in Fig. 12 indicate that Endo-polygalacturonase enzyme was secreted from both organisms. The results were also showed that Botrytis cinerea was more active than $T$. harzianum when they grow separately; in addition to ethylene was stimulator for Botrytis cinerea only, however it couldn't affect $T$. 
harzianum .Moreover, the total enzyme production was reduced in dual culture than each organism alone. The reduction of the production in such case is due to the mycoparasitism relationship. In this line, Sicilia et al. (2005) stated that during infection with Botrytis cinerea, it secretes several endopolygalacturonases (PGs) to degrade cell wall pectin, and is constitutively an important virulence factor. In the same regard, ethylene seems to be stimulator for the defense mechanism by enzymes from the hosts (Rakwal et al., 2004). In addition, virulence of the $B$. cinerea strain B05.10 on pear fruits was dependent on the polygalacturonase gene $B \operatorname{cpg} 1$, but not on the pectin methyl esterase gene Bcpme1. (Akagi \& Stotz, 2007).

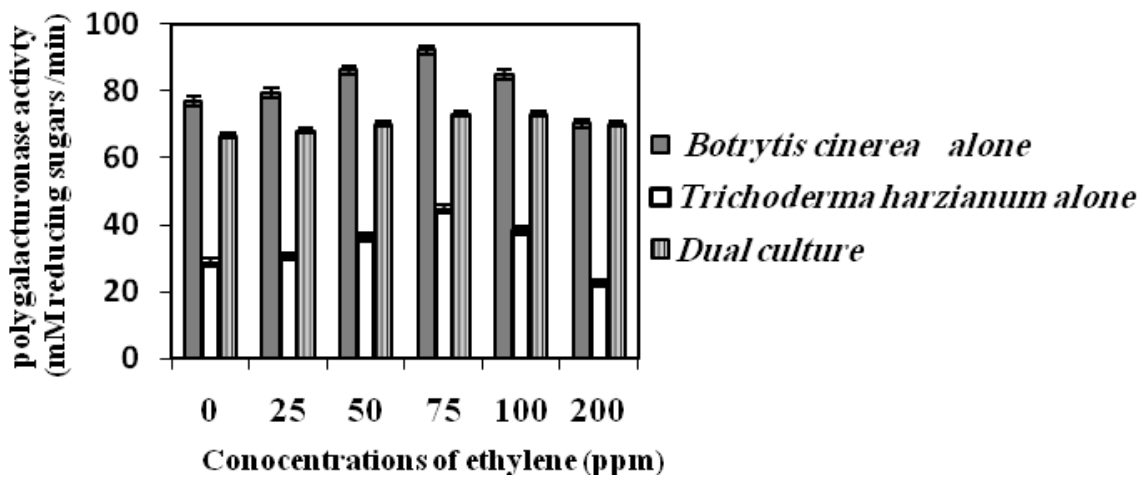

Fig. 12. Effect of different ethylene concentrations on Endo-polygalacturonase activity secreted by Botrytis cinerea and Trichoderma harzianum in both separate and in dual culture.

The results (Fig. 13) show that both Endo-chitinase and glucanases were stimulated significantly as the concentration of ethylene was increased than control where no ethylene was supplied. The results were also indicated that both enzymes were stimulated in presence of Botrytis cinerea than that of $T$. harzianum when cultivated alone. Therefore, the presence of the pathogen and ethylene could increase the mycoparastism by $T$. harzianum which reached maxima at $100 \mathrm{ppm}$ of ethylene gas .In this respect, Some isolates interferes with $B$. cinerea enzymes (Elad \& Stewart, 2004). The fact that ethylene is a known inducer for several pathogen defense-related enzymes, e.g. peroxidase, glucanase, and chitinase, lends support to the regulative role of ethylene in resistance responses (Ohme-Takagi et al., 2000). In this regard ,they can hydrolyze in vitro Botrytis cinerea cell walls and inhibits spore germination and germ tube elongation of various fungi (Lorito et al., 1994 and Schirmböck et al., 1994). 


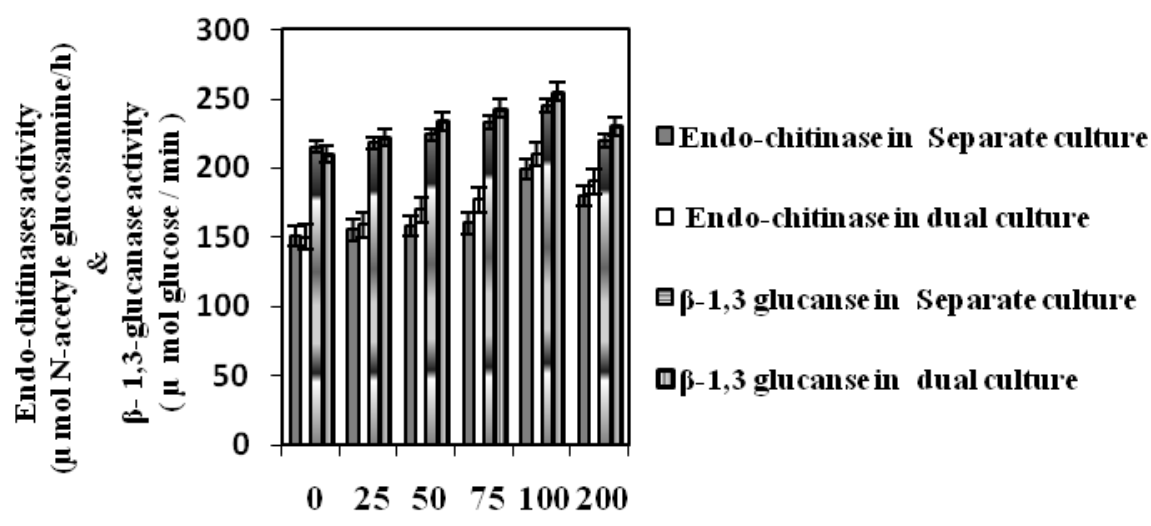

Concentrations of ethylene (ppm)

Fig. 13. Effect of different ethylene concentrations on Endo-chitinases and $\beta-1,3$ glucanases activity secreted by Trichoderma harzianum in both separate and in a dual culture.

\section{Conclusion}

The conclusion consists in that the presence of growth regulators affect the ability of T. harzianum Refai to control both A. solani and Botrytis cinerea isolated from infected tomato fruits. The stimulation of $T$. harzianum antagonisity by IAA or $\mathrm{GA}_{3}$ alone or in combination occurred in the presence of the two organisms together although, it stimulates the phytopathogen activity. Not many studies are available regarding the role of ethylene in the establishment of mycoparasitism relationships. The results of this study indicated that ethylene gas could increase the phytopathogencity of Botrytis cinerea in vitro at low concentration while the increase in the concentrations inhibits its pathogencity in the presence of $T$. harzianum.

Acknowledgement: The author is grateful to Prof. Dr. Salem, F.A., Faculty of Agriculture, Ain Shams University for kindly providing help in measure of ethylene. The author is also grateful to Dr. Mohamed, A.M.A., Faculty of Education, Ain Shams University for IAA and GA3 support.

\section{References}

Akagi, A. and Stotz, H. U. (2007) Effects of pathogen polygalacturonase ,ethylene and firmness on interactions between pear fruits and Botrytis cinerea. Plant Dis. 91,1337 1344.

Aub, M., Chiong, M. and Perez, L. M. (1993) Effect of foliar nutrients , fungicides, temperature and metal ions on pectate lyase and polygalacturonase from Alternaria alternata found in association with sooty molds in Citrus trees. Fitopatologia, 28, 38-44. 
Badri, M., Zamani , M. R. and Motallebi, M. (2007) Effect of growth regulators on in vitro biological control of Fusarium oxysporum by Trichoderma harzianum (T8) . Pakistan J. of Biological Sciences, 10 (17), 2850-2855.

Baker, B., Zambryski, P., Staskawicz, B. and Dinesh-Kumar, S. P. (1997) Signaling in plant-microbe interactions. Science, 267, 726-733.

Barnett, H. L. and Hunter, B. H. (1998) "Illustrated Genera of Imperfect Fungi" $4^{\text {th }}$ ed., p. 218, APS: 685- 708 Press, St. Paul. Minnesota.

Chaerani, R., Smulders, M. J., van der Linden, C. G., Vosman, B., Stam, P. and Voorrips, R. E. (2007) QTL identification for early blight resistance (Alternaria solani) in a Solanum lycopersicum x S. arcanum cross,Theor Appl. Genet. 114(3), 439-50.

Chagué, V., Elad ,Y., Barakat, R., Tudzynski , P. and Sharon, A. (2002) Ethylene biosynthesis in Botrytis cinerea FEMS, Microbiology Ecology, 40(2), 143-149.

Cristescu, S. M., de Martinis, D. D., te Lintel Hekkert, S. , Parker, D. H. and Harren, F. J. M. (2002) Ethylene production by Botrytis cinerea in vitro and in tomato fruit. Appl. Environ Microbiol. 68,5342-5350.

De la Cruz, J., Hidalgo-Gallego, A., Lora, J. M., Benítez, T., Pintor-Toro, J. A. and Llobell, A. (1992) Isolation and characterization of three chitinases from Trichoderma harzianum. Eur. J. Biochem. 206, 859-867.

Díaz, J., Ten Have, A. and Van Kan, J. A. L. ( 2002) The role of ethylene and wound signaling in resistance of tomato to Botrytis cinerea. Plant Physiol. 129, 1341-1351.

Elad, Y. and Eversen, K. (1995) Physiological aspects of resistance to Botrytis cinerea. Phytopathology, 85, 637-643.

Elad. Y. and Stewart, A. (2004) Microbial control of Botrytis spp. In: "Botrytis: Biology, Pathology and Control" Elad Y., Williamson, B., Tudzynski P., Delan N. (Ed.). pp.223-41. Dordrecht, the Netherlands Kluwer Academic.

Ellis, M. B. (1971) Dematiaceous Hyphomycetes. p. 608, Commonwealth Mycological Institute, Kew,England.

Ghisalberti, E. L. and Sivassithamparam, K. (1991) Antifungal antibiotics produced by Trichoderma sp. Soil Biol. Biochem. 23, 1011-1020.

Gilman, C. J. (1957) "A. Manual of Soil Fungi" (2 $2^{\text {nd }}$ ed.) Iowa State College Press, USA.

Gryndler, M., Hrselova, H., Chvatalova, I. and Jansa, J. (1998) The effect of selected plant hormones on in vitro proliferation of hyphae of Glomus fistulosum. Biol.Plant.41, 255-263.

Hanson, L. E. and Howell, C. R. (2004) Elicitors of plant disease responses from biocontrol strains of Trichoderma virens. Phytopathology, 94, 171- 6. 
Haram, S., Schickler, H., Oppenheim, A. and Chet, I. (1996) Differential expression of Trichoderma harzianum chitinases during mycoparasitism. Phytopathology, 86, 980-985.

Joo, G. J., Kim, Y. M., Kim, J. T., Rhee, I. K., Kim, J. H. and Lee, I. J. (2005) Gibberellins-producing rhizobacteria increase endogenous gibberellins content and promote growth of red peppers. J. Microbiol. 43(6), 510-5.

Jouanneau, J. P., Lapous, D. and Guern, J. (1991) In plant protoplasts, the spontaneous expression of defense reactions and the responsiveness to exogenous elicitors are under auxin control. Plant Physiol. 96,459-466.

Kennedy, R. A., Wakeham, J. Byrne, K. G., Meyer, U. M. and Dewey, F. M. (2000) A new method to monitor airborne inoculum of the fungal plant pathogens Mycosphaerella brassicicola and Botrytis cinerea. Appl Environ Microbiol. 66(7), 2996-3003.

Kim, G. H. and Wills, R. B. H. (1995) Effect of ethylene on storage life of lettuce. Journal of the Science of Food and Agriculture, 69, 197-201.

Knoester, M., van Loon, L.C. Van den Heuvel, J., Hennig, J., Bol, J. F. and Linthorst, H. J. M. (1998) Ethylene-insensitive tobacco lacks nonhost resistance against soil-borne fungi. Proceedings of the National Academy of Sciences, USA . 95,1933-1937.

Kritzman, G. and Netzer, D. (1978) A selective medium for isolation and identification of Botrytis spp. from soil and onion seed. Phytoparasitica, 6, 3-7.

Latorre, B. A., Agosin, E., Martin, R. S., Vasquez, G. S. and San Martin, R. (1997) Effectiveness of conidia of Trichoderma harzianum produced by liquid fermentation against Botrytis bunch rot of table grape in Chile. Crop Protection, 16, 209-14.

Lorito, M., Peterbauer, C., Hayes, C. K. and Harman, G. E. (1994) Synergistic interaction between fungal cell wall degrading enzymes and different antifungal compounds enhances inhibition of spore germination. Microbiology, 140,623-62.

Lu, H., Zou, W. X., Meng, J. C., Hu, J. and Tan, R. X. (2000) New bioactive metalbolites produced by Colletotrichum sp., an endophyic fungus in Artemisia annua. Plant Sci.Lim.151, 67-73.

Monte , E. (2001)Understanding Trichoderma :between biotechnology and microbial ecology . Int Microbiol. 4, 1-4.

Nelson, N. (1944) A photometric adaptation of the Somogyi method for the determination of glucose. Journal of Biological Chemistry, 153,375-380.

Ohme-Takagi, M., Suzuki, K. and Shinshi, H. (2000) Regulation of ethylene-induced transcription of defense genes. Plant Cell Physiol. 41, 1187-1192.

Pérez, L. M., Mettifogo, S., Zaldívar, M. and Musalem, M. (1991) Sooty molds infecting citrus species in Chile: identification of the associated fungi and their ability to secrete plant cell wall hydrolyzing enzymes. Fitopatología , 26,28-38.

Egypt. J. Microbiol. 43 (2008) 
Polevaya, Y., Alkalai-Tuvia, S., Copel, A. and Fallik, E. (2002) Early detection of grey mould development in tomato after harvest. Postharvest Biol. Technol. 25, 221-225.

Pu Liu Eugene and Nester, W. (2006) Indole acetic acid, a product of transferred DNA, inhibits vir gene expression and growth of Agrobacterium tumefaciens C58, Proc. Natl. Acad. Sci. USA. 103 (12), 4658-4662.

Qadir, A., Hewett, E. W. and Long,P. G. (1997) Ethylene production by Botrytis cinerea. Postharvest Biol. Technol. 11, 85-91.

Rakwal, R., Yang, G. and Komatsu ,S. (2004) Chitinase induced by jasmonic acid, methyl jasmonate, ethylene and protein phosphatase inhibitors in rice. Mol Biol Rep. 31(2),113-9.

Rey, M., Delgado Jarana, J. and Benitez, T. (2001) Improved antifungal activity of a mutant of Trichoderma harzianum CECT 2413 which produces more extracellular proteins. Applied Microbiology and Biotechnology, 55, 604- 8.

Robert, H. C. and Jane Gradwohl, N. (2005) Doing data analysis for windows with SPSS: Version 14.0

Robinette, D. and Matthysse, A. G. (1990) Inhibition by Agrobacterium tumefaciens and Pseudomonas savastanoi of development of the hypersensitive response elicited by Pseudomonas syringae, Pseudomonas syringae pv. phaseolicola.phaseolicola. J. Bacteriol. 172, 5742-5749.

Roco, A. and Pérez, L. (2001) In vitro biocontrol activity of Trichoderma harzianum on Alternaria alternata in the presence of growth regulators .EJB Electronic Journal of Biotechnology, 4, 1-6.

Rojas-Avelizapa, I. I., Cruz-Camarillo, R., Guerrero, R., Rodriguez-Vazquez and Ibar, J. E. (1999) Selection and characterization of a proteo-chitinolytic strain of Bacillus thuringinensis able to grow in shrimp waste media .World J. Microbiol.15, 261-268.

Roze, L. V., Calvo, A. M., Gunterus, A., Beaudry, R., Kall, M. and Linz, J.E. (2004) Ethylene modulates development and Toxin biosynthesis in Aspergillus possibly via an ethylene sensor-mediated signaling pathway. J Food Prot. 67,438-447

Santos, T., Villanueva, J. R. and Nombela, C. (1977) Production and catabolite repression of Penicillium italicum $\beta$-glucanases. J. Bacteriol. 29, 52-58.

Schirmböck, M., Lorito, M., Wang, Y. L., Hayes, C. K., Arsian-Atac, I., Scalar, F., Harman, G. E. and Kubicek, C. P. (1994) Parallel formation and synergism of hydrolytic enzymes and peptabiol antibiotics: molecular mechanisms involved in the antagonistic action of Trichoderma harzianum against phytopathogenic fungi. Appl. Environ. Microbiol. 60, 4364-437

Schmitt, A., Kunz , S., Nandi, S., Seddon, B. and Ernst, A . (2002) Use of Reynoutria sachalinensis plant extracts, clay preparations and Brevibacillus brevis against fungal diseases of grape berries. Proceedings of the $10^{\text {th }}$ International Conference on Cultivation Technique and Phytopathological Problems in Organic

Egypt. J. Microbiol. 43 (2008) 
Fruit-Growing and Viticulture Weinsberg, Germany. Weinsburg, Germany: FOKO. pp. 146-51.

Sharaf, E. F. and Farrag, A. A. (2004) Induced resistance in tomato plants by IAA against Fusarium oxysporum lycopersici. Polish journal of Microbiology, 53, (2), 111-116.

Shibuya, N. and Minami, E. (2001) Oligosaccharide signalling for defence responses in plant. Physiol. Mol. Plant Patrol. 59, 223-233.

Sicilia, F., Fernandez-Recio, J., Caprari, C., De Lorenzo, G., Sernoglou, M., Cervone, F. and Federici , L. (2005) The Polygalacturonase-inhibiting protein PGIP2 of Phaseolus vulgaris has evolved a mixed mode of inhibition of Endopolygalacturonase PG1 of Botrytis cinerea, Plant Physiol. 139(3), 1380-1388.

Simona, M. C., Domenico, D. M., Te Lintel Hekkert, S., Parker, D. H. and Harren, F. J. M. (2002) Ethylene Production by Botrytis cinerea in vitro and in tomatoes . Appl Environ Microbiol. 68(11), 5342-5350.

Strobel, G. and Daisy, B. (2003) Bioprospecting for microbial endophytes and their natural products. Microbiol. Mol. Biol. Rev. 2003 December; 67(4), 491-502.

Thomma, B. P. H. J. , Eggermont, K., Tierens, K. F. M. J. and Broekaert, W. F. (1999) Requirement of functional ethylene-insensitive 2 gene for efficient resistance of Arabidopsis to infection by Botrytis cinerea. Plant Physiol. 121, 1093-1101.

Tudzynski, B. and Sharon, A. (2002) Biosynthesis, biological role and application of fungal hormones. In: "The Mycota X: Industrial Applications". Osiewacz, H.D. (Ed.), pp.183-211, Springer-Verlag, Berlin,Heidelberg.

Whipps, J. M. (1992) Status of biological disease control in horticulture. Biocontrol Sci. Technol. 2, 3-24.

Zimand, G., Elad, Y. and Chet, I. (1996) Effect of Trichoderma harzianum on Botrytis cinerea pathogenicity. Phytopathology, 86, 1255-1260.

(Received 12/2/2008; accepted 16/4/2008) 


\section{تأثير حمض الجبريلك، اندول حمض الخليك وغاز الأثيلين معمليًا

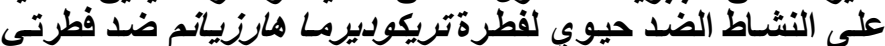

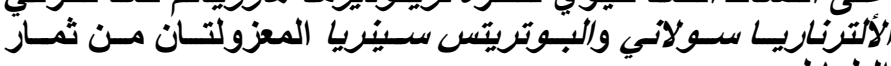 \\ الطماطم}

محمد عبد العزيز فؤاد

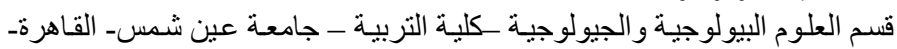

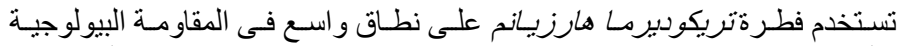

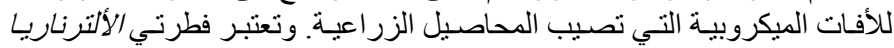

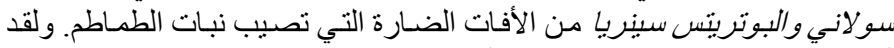

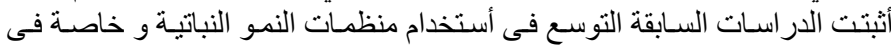
الفترة الأخيرة للعديد من الأسباب والتى قلى تؤثر على النشاط الفطري.

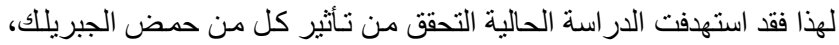

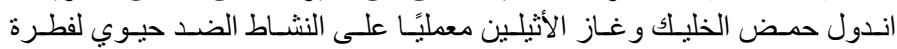

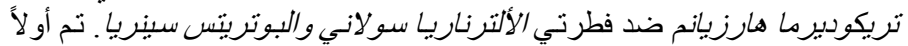

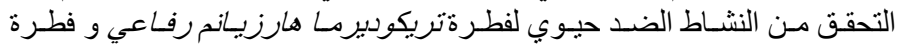

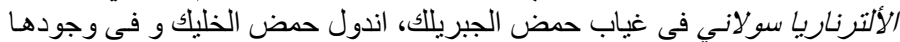

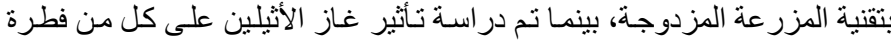
تريكوديرما هارزيانم رفاعي و فطرة البوتريتس سبنيريا.

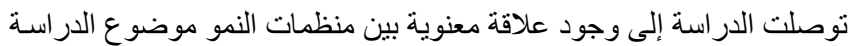

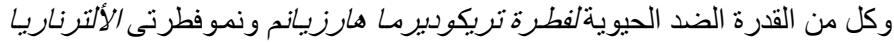

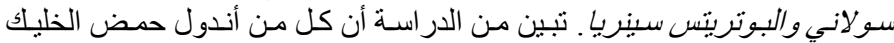

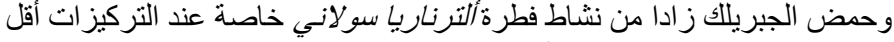

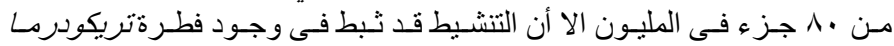

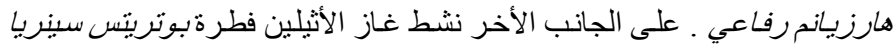

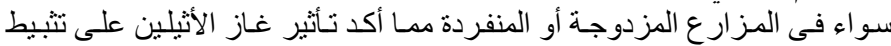

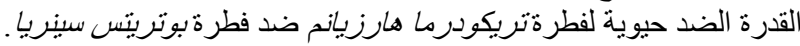

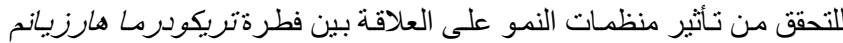

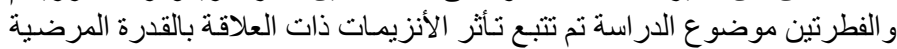

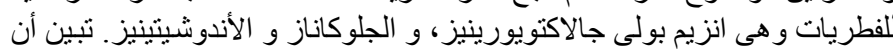

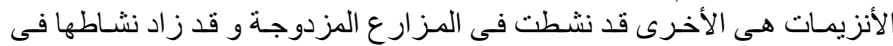

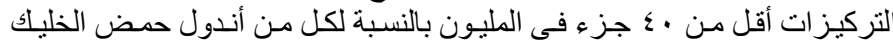

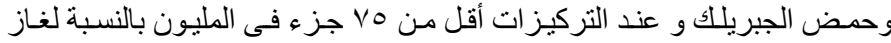

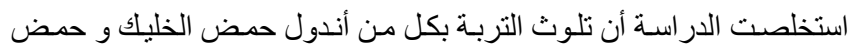

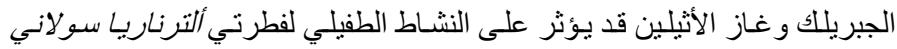

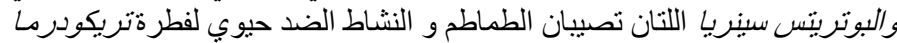
هارزيانم، ولهذا فالدر اسة تحتاج الى تجان الهارب حقلية أخرى.

Egypt. J. Microbiol. 43 (2008) 